\title{
MDM2 SNP309, gene-gene interaction, and tumor susceptibility: an updated meta-analysis
}

Yan Wan ${ }^{1,2,3}$, Wei Wu $u^{1,2,3}$, Zhihua Yin ${ }^{1,2,3}$, Peng Guan ${ }^{1,2,3}$ and Baosen Zhou ${ }^{1,2,3^{*}}$

\begin{abstract}
Background: The tumor suppressor gene $p 53$ is involved in multiple cellular pathways including apoptosis, transcriptional control, and cell cycle regulation. In the last decade it has been demonstrated that the single nucleotide polymorphism (SNP) at codon 72 of the p53 gene is associated with the risk for development of various neoplasms. MDM2 SNP309 is a single nucleotide T to G polymorphism located in the MDM2 gene promoter. From the time that this well-characterized functional polymorphism was identified, a variety of case-control studies have been published that investigate the possible association between MDM2 SNP309 and cancer risk. However, the results of the published studies, as well as the subsequent meta-analyses, remain contradictory.
\end{abstract}

Methods: To investigate whether currently published epidemiological studies can clarify the potential interaction between MDM2 SNP309 and the functional genetic variant in $p 53$ codon72 (Arg72Pro) and p53 mutation status, we performed a meta-analysis of the risk estimate on 27,813 cases with various tumor types and 30,295 controls.

Results: The data we reviewed indicated that variant homozygote 309GG and heterozygote 309TG were associated with a significant increased risk of all tumor types (homozygote comparison: odds ratio $(O R)=1.25,95 \%$ confidence interval $(\mathrm{Cl})=1.13-1.37$; heterozygote comparison: $\mathrm{OR}=1.10,95 \% \mathrm{Cl}=1.03-1.17)$. We also found that the combination of GG and Pro/Pro, TG and Pro/Pro, GG and Arg/Arg significantly increased the risk of cancer (OR $=3.38,95 \% \mathrm{Cl}=1.77-6.47 ; \mathrm{OR}=1.88,95 \% \mathrm{Cl}=1.26-2.81 ; \mathrm{OR}=1.96,95 \% \mathrm{Cl}=1.01-3.78$, respectively). In a stratified analysis by tumor location, we also found a significant increased risk in brain, liver, stomach and uterus cancer (OR $=1.47,95 \% \mathrm{Cl}=1.06-2.03 ; \mathrm{OR}=2.24,95 \% \mathrm{Cl}=1.57-3.18 ; \mathrm{OR}=1.54,95 \% \mathrm{Cl}=1.04-2.29 ; \mathrm{OR}=1.34,95 \% \mathrm{Cl}=1.07-$ 1.29, respectively). However, no association was seen between MDM2 SNP309 and tumor susceptibility in the stratified analysis by p53 mutation status (GG vs $\Pi$ : $\mathrm{OR}=1.17,95 \% \mathrm{Cl}=0.75-1.82$ and TG vs $T$ : $\mathrm{OR}=1.09,95 \% \mathrm{Cl}$ $=0.89-1.34$ for positive p53 mutation status; GG vs $T$ : $\mathrm{OR}=0.95,95 \% \mathrm{Cl}=0.72-1.25$ and TG vs $T$ : $\mathrm{OR}=1.06,95 \%$ $\mathrm{Cl}=0.85-1.30$ for negative $p 53$ mutation status).

Conclusions: The analyses indicate that MDM2 SNP309 serves as a tumor susceptibility marker, and that there is an association between MDM2 SNP309 and p53 Arg72Pro regarding tumor susceptibility. Further studies that take into consideration environmental stresses and functional genetic variants in the p53-MDM2-related genes are warranted.

\section{Background}

The p53 protein is a principal mediator of growth arrest, apoptosis, and senescence in response to an array of cellular damage [1-3]. Various types of stress can induce high levels of p53 protein, thus preventing inappropriate propagation of stressed cells. Because of this protein's vital role in maintaining normal cellular function, tumor cells have developed numerous methods to disable its

\footnotetext{
* Correspondence: bszhou@mail.cmu.edu.cn

'Department of Epidemiology, School of Public Health, China Medical University, Shenyang 110001, China

Full list of author information is available at the end of the article
}

function. Indeed, the p53 protein is inactivated by mutations or deletions in approximately $50 \%$ of human cancers [4]. A polymorphism at codon 72 with a single-base change in the $p 53$ gene causes an amino acid replacement in the transaction domain of the protein Arg (CGC) with Pro (CCC). Although the functional differences of these two variants of the p53 protein remain unclear, it has been demonstrated that a single nucleotide polymorphism (SNP) at codon 72 of the $p 53$ gene is associated with the risk for development of various neoplasms. However, in the rest of human tumor types, the $p 53$ gene remains in a wild-type form and its activity

\section{() Biomed Central}


is eradicated by its principal cellular inhibitor, murine double minute 2 protein (MDM2) [5].

MDM2 is the primary regulator of p53. MDM2 and p53 regulate each other through a feedback loop. In this mechanism, p53 induces MDM2, and MDM2 then acts as an E3 ubiquitin ligase that exports p53 out of the nucleus and promotes its degradation [6]. Moreover, MDM2 is capable of affecting genome stability in a p53-independent way [7]. A functional single-nucleotide $\mathrm{T}$ to $\mathrm{G}$ polymorphism is present in the promoter of the MDM2 gene (rs2279744), known as MDM2 SNP309[8]. Bond et al. demonstrated that the GG genotype of SNP309 enhanced the affinity of the transcription factor Sp1 to the $M D M 2$ promoter in cell lines, and consequently enhanced the expression of MDM2 RNA and protein, resulting in a possible attenuation of the p53 pathway [9]. In both patients with hereditary Li-Fraumeni syndrome (one $p 53$ allele mutated) and patients with sporadic soft tissue sarcoma, the presence of the SNP309 G-allele accelerated tumor formation $[10,11]$.

To date, a number of studies have explored the association between MDM2 SNP309 and the risk of various types of cancer [12-77], including brain, breast, colorectal, hepatocellular, lung, ovarian, gastric, uterus, and so on. Nearly three years since the meta-analysis was performed by $\mathrm{Hu}$ et al. [78], forty-one additional case-control studies regarding the association between SNP309 and tumor risk have appeared, which is a greater number of studies than the number of studies included in the original meta-analysis. Therefore, an updated metaanalysis is needed. The meta-analysis presented in this study aims to assess whether MDM2 SNP309 is associated with cancer risk and to investigate the possible interaction between MDM2 SNP309 and p53 mutation status and the $p 53$ codon 72 polymorphism.

\section{Methods}

\section{Primary search strategy}

We searched the Pub Med and CNKI databases for all genetic association studies published to date on the MDM2 SNP309 and tumor risk (the most recent search update was April 2, 2010). To perform the search we used the subject terms " $M D M 2$ polymorphism(s) and tumor". Only English-language and Chinese-language papers were included. The references cited in the original studies or review articles concerning the relevant topic were retrieved in order to potentially broaden the search with additional relevant publications.

\section{Criteria for study inclusion and exclusion}

All studies reporting human associations that met the following criteria, regardless of sample size, were included in this meta analysis; if not, the studies were excluded: (a) the study is a case-control study on the association of MDM2 SNP309 and tumor susceptibility; (b) the study reports genotypic frequencies of $M D M 2$ SNP309 in cancer patients and controls; (c) the genotype of the control population is in Hardy-Weinberg equilibrium. If the study had the same population resource or had overlapping subjects, only the study reporting the largest population was selected. Hence, we included sixty-six studies in our meta-analysis, containing 27,813 cases with different tumor types and 30,295 controls.

\section{Data extraction}

Two reviewers independently extracted data using a standardized extraction form. For each case, if a disparity was identified the two reviewers debated until a consensus was reached on all items. The following information was collected from each publication: the first author's name, year of publication, tumor type, ethnicity, genotype frequency for cases and controls, minor allele frequency (MAF) in controls, $p 53$ mutation status, and interaction with $p 53$ Arg72Pro status (Additional file 1). If a study contained more than one tumor type or ethnicity, genotype data were extracted separately according to tumor type or ethnicity for subgroup analyses. Racial descent was classified as European, Asian, African, and mixed.

\section{Statistical analysis}

Odds ratios (ORs) were pooled to evaluate the association between MDM2 SNP309 and tumor risk. The fixed effect model and the random effect model based on the Mantel-Haenszel method and the Dersimonian and Laird method, respectively, were used to pool data from different studies. If the heterogeneity between studies is absent, these two models provide similar results; otherwise, it is more appropriate to adopt the random effect model. We first compared the tumor risk in the variant homozygote GG and in the heterozygote TG with the wild-type TT homozygote. The ORs and 95\% CIs were calculated. The statistical significance of the OR was determined using the $\mathrm{Z}$ test. Statistical heterogeneity between studies was assessed with the $\chi^{2}$-based $\mathrm{Q}$ test and $\mathrm{I}^{2}$, heterogeneity was considered significant when $\mathrm{P}$ $<0.1$, and $\mathrm{I}^{2}$ was used to qualify variation in OR attributable to heterogeneity. Crossover analysis was used for interaction analysis.

Publication bias was investigated using the funnel plot, a method used to analyze subjective data. To supplement the funnel plot method, we also adopted the liner regression approach proposed by Egger et al. ORs and $95 \%$ CIs were generated by meta-analysis using STATA (version 10.0). 


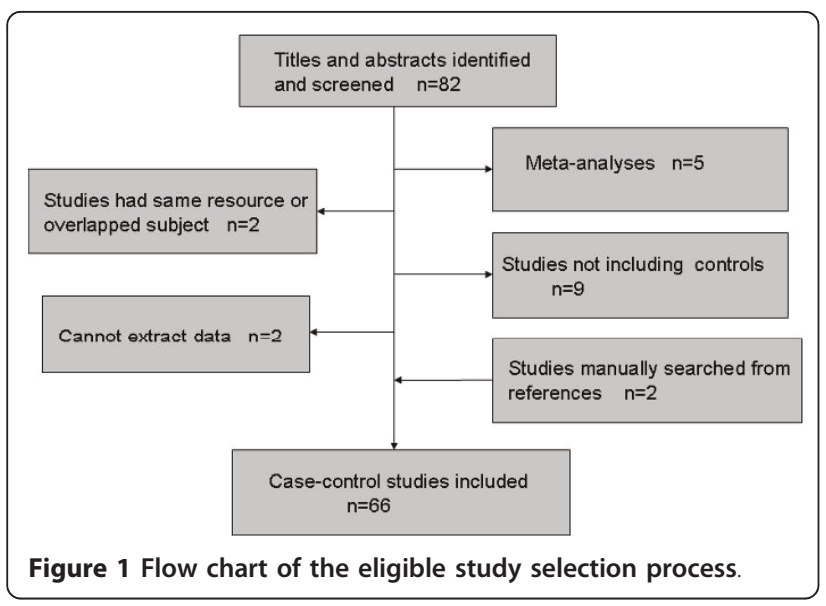

\section{Results}

\section{Characteristics of studies}

After screening the titles and abstracts, a total of eightytwo full text articles were reviewed to identify eligibility for our systematic review. According to the inclusion criteria, we found that five articles were meta-analyses [78-82], two studies utilized the same population resource or contained overlapping subjects, nine articles did not include controls, and for two studies we were unable to extract the data. In addition, we included two studies $[23,35]$ that were retrieved manually from the original articles' references. Thus, for our systematic-review, we summarized the results of sixty-six case-control studies [12-77], including sixty-three English language articles and three Chinese language articles $[36,39,57]$ and containing seventy-eight comparisons (Figure 1).

The detailed characteristics of the sixty-six case-control studies are shown in Additional file 1. These studies contain thirty tumor types, and the racial descent of the subjects is classified as European, Asian, African, and mixed. The genotype distribution observed in the controls was consistent with the Hardy-Weinberg equilibrium for all studies. There were ten studies in which the $p 53$ mutation status was detected in tumor cases, but only seven of these studies presented the MDM2 SNP309 genotype distributions according to $p 53$ mutation status $[16,20,35,37,41,54,70]$. There were twelve studies that investigated the interaction of MDM2 SNP309 and p53 codon72 polymorphism on cancer risk; however, only six studies $[19,28,46,51,60,72]$ offered detailed data (Table 1).

\section{Quantitative synthesis}

There was wide variation in the MDM2 309G allele frequency in the different ethnic groups (Additional file 1). The mean frequency of the $G$ allele was 0.11 for African, 0.37 for European, 0.50 for Asian, and 0.36 for mixed ethnicities.

When all of the eligible studies were pooled, we found that the variant genotypes were associated with increased tumor risk in several genetic models. The variant homozygote GG exhibited a significantly increased risk for all tumor types when compared with the wild-type TT homozygote $(\mathrm{OR}=1.25,95 \% \mathrm{CI}=1.13-1.37 ; \mathrm{P}<0.001$ for heterogeneity test; $\mathrm{I}^{2}=66.9 \%$ for heterogeneity). Interestingly, we also found that the variant heterozygote TG exhibited an increased risk for all tumor types $(\mathrm{OR}=$ $1.10,95 \% \mathrm{CI}=1.03-1.17 ; \mathrm{P}<0.001$ for heterogeneity test; $\mathrm{I}^{2}=51.7 \%$ for heterogeneity). Significant effects were also found both in the recessive and dominant models (recessive model: $\mathrm{OR}=1.18,95 \% \mathrm{CI}=1.10-1.27 ; \mathrm{P}<0.001$ for heterogeneity test; $\mathrm{I}^{2}=55.1 \%$ for heterogeneity; dominant models: $\mathrm{OR}=1.14,95 \% \mathrm{CI}=1.07-1.22 ; \mathrm{P}<0.001$ for heterogeneity test; $\mathrm{I}^{2}=62.2 \%$ for heterogeneity; Table 2 ).

Subsequently, we investigated the effects of MDM2 SNP309 stratified by tumor location, ethnicity, and $p 53$ mutation status. We found that there was an association between individuals with the GG genotype or TG genotype and an elevated risk of breast, brain, liver, stomach, and uterus cancer when compared to subjects with the TT genotype (Table 2). Interestingly, the risk was significant in brain, liver, and stomach cancer. Regarding the different ethnic groups, we found a subtle cancer risk in the European population $(\mathrm{OR}=1.13,95 \% \mathrm{CI}=1.01-1.25)$ and a significant cancer risk in the Asian population (OR $=1.36,95 \% \mathrm{CI}=1.18-1.56)$. However, no significant associations were found in either the $p 53$ mutation-positive or $p 53$ mutation-negative subgroup (Table 2).

Table 1 Datas for the interaction of p53 codon72 polymorphism and MDM2 SNP309 for tumor susceptibility

\begin{tabular}{|c|c|c|c|c|c|c|c|}
\hline \multirow{2}{*}{$\begin{array}{l}\text { First author } \\
\text { (reference ) }\end{array}$} & \multirow[t]{2}{*}{ Tumor site } & \multicolumn{2}{|c|}{ 309TT } & \multicolumn{2}{|c|}{ 309TG } & \multicolumn{2}{|c|}{ 309GG } \\
\hline & & Case* & Control* & Case* $^{*}$ & Control* & Case* & Control* \\
\hline Yang $\mathrm{M}$ & GCA & $19 / 61 / 27$ & $96 / 150 / 52$ & $59 / 119 / 72$ & $162 / 222 / 114$ & $45 / 65 / 33$ & $58 / 114 / 32$ \\
\hline Singh V & $\mathrm{BC}$ & $10 / 11 / 4$ & $4 / 18 / 3$ & $23 / 21 / 4$ & $13 / 32 / 2$ & $13 / 13 / 5$ & $11 / 15 / 7$ \\
\hline Yoon YJ & $\mathrm{HCC}$ & $23 / 18 / 4$ & $40 / 38 / 6$ & $48 / 58 / 19$ & $56 / 53 / 23$ & $39 / 35 / 43$ & $28 / 45 / 8$ \\
\hline Xiong XJ & $\mathrm{AML}$ & $6 / 22 / 4$ & $12 / 17 / 6$ & $29 / 62 / 32$ & $22 / 33 / 13$ & $17 / 43 / 16$ & $5 / 14 / 6$ \\
\hline Zhang $X$ & LC & $62 / 127 / 60$ & $122 / 222 / 74$ & $170 / 259 / 132$ & $223 / 343 / 145$ & $89 / 120 / 87$ & $80 / 166 / 45$ \\
\hline Cox DG & $B C$ & $349 / 218 / 40$ & $488 / 346 / 60$ & $317 / 266 / 45$ & $539 / 365 / 52$ & $104 / 63 / 14$ & $166 / 92 / 10$ \\
\hline
\end{tabular}

*P53 codon72 wild-type homozygote/heterozygote/variant homozygote 
Table 2 Summary OR $(95 \% \mathrm{Cl})$ and I-squre for various contrasts of the MDM2 SNP309 polymorphism and tumor risk

\begin{tabular}{|c|c|c|c|c|c|c|c|c|c|}
\hline \multirow[t]{2}{*}{ Subgroup } & \multirow{2}{*}{$\begin{array}{c}\text { No. } \\
\text { comparisons }\end{array}$} & \multicolumn{2}{|l|}{ TG vs. TT } & \multicolumn{2}{|l|}{ GG vs. TT } & \multicolumn{2}{|c|}{ GG vs. TT/TG } & \multicolumn{2}{|c|}{ GG/TG vs. TT } \\
\hline & & OR $(95 \% \mathrm{Cl})$ & $\begin{array}{c}\text { I-squre } \\
(\%)\end{array}$ & OR $(95 \% \mathrm{Cl})$ & $\begin{array}{c}\text { I-squre } \\
(\%)\end{array}$ & OR $(95 \% \mathrm{Cl})$ & $\begin{array}{c}\text { I-squre } \\
(\%)\end{array}$ & OR $(95 \% \mathrm{Cl})$ & $\begin{array}{c}\text { I-squre } \\
(\%)\end{array}$ \\
\hline Total & 78 & $1.10 *(1.03-1.17)$ & 51.7 & $1.25^{*}(1.13-1.37)$ & 66.9 & $\begin{array}{c}1.18 *(1.10- \\
1.27)\end{array}$ & 55.1 & $1.14 *(1.07-1.22)$ & 62.2 \\
\hline \multicolumn{10}{|l|}{ Tumor site } \\
\hline Breast & 18 & $1.09 *(1.00-1.19)$ & 12.8 & $1.09(0.96-1.24)$ & 20.7 & $1.05(0.94-1.17)$ & 19.5 & $1.09 *(1.01-1.17)$ & 9.1 \\
\hline Lung & 10 & $1.06(0.93-1.22)$ & 64.8 & $1.21(0.99-1.47)$ & 67.8 & $1.12(0.99-1.27)$ & 42.7 & $1.10(0.95-1.27)$ & 72.4 \\
\hline Ovarian & 3 & $0.85(0.63-1.16)$ & 25.2 & $0.79(0.48-1.28)$ & 52.3 & $0.89(0.63-1.25)$ & 33.1 & $0.82(0.57-1.18)$ & 50.5 \\
\hline Pancreatic & 2 & $1.55(0.98-2.46)$ & 59 & $1.56(0.66-3.68)$ & 74.6 & $1.24(0.68-2.24)$ & 56.4 & $1.54(0.90-2.65)$ & 73 \\
\hline Blood & 4 & $1.08(0.65-1.79)$ & 79.4 & $1.11(0.57-2.17)$ & 80.3 & $1.09(0.71-1.68)$ & 63.8 & $1.10(0.67-1.82)$ & 81.6 \\
\hline Brain & 5 & $1.47^{*}(1.06-2.03)$ & 57.6 & $1.18^{*}(1.08-3.03)$ & 69.5 & $1.38(0.94-2.01)$ & 55.9 & $1.51 *(1.10-2.07)$ & 61.3 \\
\hline Colorectal & 6 & $1.14(0.89-1.47)$ & 51.2 & $1.05(0.65-1.68)$ & 74.4 & $1.00(0.67-1.49)$ & 70 & $1.13(0.85-1.50)$ & 65.5 \\
\hline Esophageal & 2 & $1.11(0.86-1.43)$ & 36 & $1.26(0.92-1.72)$ & 51.2 & $1.28(0.97-1.69)$ & 63.1 & $1.18(1.00-1.41)$ & 0 \\
\hline Head-neck & 4 & $0.92(0.67-1.28)$ & 71.6 & $1.01(0.69-1.47)$ & 72.3 & $1.11(0.96-1.29)$ & 1.7 & $0.94(0.67-1.34)$ & 77.8 \\
\hline Liver & 4 & $1.57^{*}(1.18-2.09)$ & 0 & $2.24 *(1.57-3.18)$ & 0 & $\begin{array}{l}1.65^{*}(1.25- \\
2.17)\end{array}$ & 0 & $1.76 *(1.34-2.31)$ & 0 \\
\hline Skin & 4 & $1.00(0.86-1.16)$ & 0.4 & $1.05(0.85-1.29)$ & 1.2 & $1.05(0.86-1.27)$ & 0 & $1.01(0.86-1.19)$ & 26.6 \\
\hline Stomach & 5 & $1.03(0.75-1.42)$ & 72.2 & $1.54^{*}(1.04-2.29)$ & 76.4 & $\begin{array}{c}1.49 *(1.20- \\
1.84)\end{array}$ & 53.2 & $1.18(0.84-1.65)$ & 77.6 \\
\hline Uterus & 8 & $0.95(0.81-1.11)$ & 0 & $1.34 *(1.07-1.69)$ & 5.3 & $1.26(0.92-1.72)$ & 51.2 & $0.81 *(0.70-0.94)$ & 0 \\
\hline Other & 3 & $0.98(0.72-1.32)$ & 14.6 & $1.14(0.63-2.08)$ & 66.8 & $1.16(0.72-1.85)$ & 62.6 & $1.02(0.67-1.52)$ & 55 \\
\hline \multicolumn{10}{|l|}{$\begin{array}{l}\text { Racial } \\
\text { descent }\end{array}$} \\
\hline African & 3 & $1.22(0.80-1.86)$ & 61.2 & $0.75(0.40-1.41)$ & 0 & $0.73(0.39-1.36)$ & 0 & $1.16(0.80-1.70)$ & 56 \\
\hline European & 34 & $1.05(0.98-1.13)$ & 34.8 & $1.13^{*}(1.01-1.25)$ & 40.8 & $\begin{array}{l}1.10^{*}(1.00- \\
1.20)\end{array}$ & 30.8 & $1.08 *(1.00-1.16)$ & 42.1 \\
\hline Asian & 32 & $1.11(0.99-1.24)$ & 58.4 & $1.36 *(1.18-1.56)$ & 68.6 & $\begin{array}{c}1.27^{*}(1.15- \\
1.40)\end{array}$ & 58.6 & $1.18 *(1.05-1.32)$ & 65.8 \\
\hline Mixed & 9 & $1.10(0.91-1.32)$ & 49.7 & $1.16(0.86-1.56)$ & 59.6 & $1.08(0.88-1.35)$ & 37.3 & $1.10(0.92-1.32)$ & 52.7 \\
\hline \multicolumn{10}{|l|}{$\begin{array}{l}\text { p53 mutation } \\
\text { status }\end{array}$} \\
\hline Positive & 7 & $1.09(0.89-1.34)$ & 0 & $1.17(0.75-1.82)$ & 59.4 & $1.09(0.70-1.69)$ & 70.3 & $1.12(0.92-1.36)$ & 0 \\
\hline Negative & 7 & $1.06(0.85-1.30)$ & 4.1 & $0.95(0.72-1.25)$ & 0 & $0.97(0.76-1.22)$ & 0 & $1.03(0.85-1.25)$ & 0 \\
\hline
\end{tabular}

*P value $<0.05$ for significance tests of $O R=1$

$\ddagger P$ value $=0.056$ for significance test of $O R=1$

\section{Gene-gene interaction}

In this meta-analysis, we pooled the eligible studies for association of MDM2 SNP309 and p53 Arg72Pro on tumor risk. In comparison to the reference $M D M 2$ $309 \mathrm{TT}$ and $p 53 \mathrm{Arg} / \mathrm{Arg}$ genotype, the OR (3.38) for subjects with the MDM2 309GG and p53 Pro/Pro genotype is larger than the OR (1.96) for subjects with the MDM2 309GG and p53 Arg/Arg or the OR (1.38) for subjects with the MDM2 309TT and p53 Pro/Pro genotype (Table 3 ). These results indicate a possible compounding effect between the MDM2 309GG and p53 Pro/Pro genotype that leads to a significantly increased risk of cancer. The p-value for the overall interaction analysis is less than 0.001 .
Table 3 Interaction of MDM2 SNP309 (T to G) and p53 Arg72Pro on tumor risk

\begin{tabular}{|c|c|c|c|c|}
\hline MDM2 309T > G & P53 72Arg > Pro & Case & Control & OR $(95 \% \mathrm{Cl})$ \\
\hline$\pi$ & Arg/Arg & 469 & 762 & Reference \\
\hline$\pi$ & Arg/Pro & 457 & 791 & $1.09(0.74-1.61)$ \\
\hline$\pi$ & Pro/Pro & 139 & 201 & $1.38(0.92-2.06)$ \\
\hline $\mathrm{TG}$ & Arg/Arg & 646 & 1015 & 1.32 (0.88-1.98) \\
\hline $\mathrm{TG}$ & Arg/Pro & 785 & 1048 & $1.51(0.96-2.38)$ \\
\hline TG & Pro/Pro & 304 & 349 & $1.88(1.26-2.81)^{*}$ \\
\hline $\mathrm{GG}$ & Arg/Arg & 307 & 348 & $1.96(1.01-3.78)^{*}$ \\
\hline GG & Arg/Pro & 339 & 446 & $1.53(0.92-2.53)$ \\
\hline GG & Pro/Pro & 198 & 108 & $3.38(1.77-6.47)^{*}$ \\
\hline
\end{tabular}

*P values $<0.05$ for significance test of $O R=1$ 
Test of heterogeneity

We observed heterogeneity between studies regarding both overall comparisons and subgroup analyses. Hence, the random effect model based on the Mantel-Haenszel method was adopted for this meta-analysis. The details of $\mathrm{I}^{2}$ for each comparison are shown in Table 2.

\section{Publication bias}

The publication bias of the studies was determined by the Funnel plot and Egger's test. As shown in Figure 2 $(\mathrm{A} / \mathrm{B} / \mathrm{C} / \mathrm{D})$, the shapes of the funnel plots appeared symmetrical in all comparisons, indicating the absence of publication bias. Next, we used Egger's test to provide statistical evidence for the funnel plot symmetry. The greater the intercept deviation from zero in linear regression analysis, the greater the possibility for asymmetry. We considered the funnel plot to be symmetrical if we observed a 95\% confidence interval with an intercept of zero. The results are shown in Table 4.

\section{Discussion}

On the basis of sixty-six case-control studies focused on MDM2 309 T/G polymorphism and tumor risk, our
Table 4 The results of egger's test for four comparisons

\begin{tabular}{ccccc}
\hline $\begin{array}{c}\text { Comparison } \\
\text { type }\end{array}$ & $\begin{array}{c}\text { Intercept } \\
\text { value }\end{array}$ & $\begin{array}{c}\text { t- } \\
\text { value }\end{array}$ & $\begin{array}{c}\text { P- } \\
\text { value }\end{array}$ & $\begin{array}{c}\mathbf{9 5 \% ~ C l ~ o f ~ i n t e r c e p t ~} \\
\text { value }\end{array}$ \\
\hline TG vs. TT & 0.24 & 0.67 & 0.507 & $-0.49 \sim 0.98$ \\
GG vs. TT & -0.07 & -0.16 & 0.87 & $-0.91 \sim 0.77$ \\
GG vs. TT/TG & -0.22 & -0.6 & 0.55 & $-0.94 \sim 0.51$ \\
GG/TG vs. TT & 0.35 & 0.87 & 0.39 & $-0.45 \sim 1.15$ \\
\hline
\end{tabular}

meta-analysis provided evidence that the variant homozygote GG and heterozygote TG were significantly associated with increased tumor risk. Our findings are in concordance with the meta-analysis conducted by $\mathrm{Hu}$ et al. which suggests that the MDM2 SNP309 serves as a low-penetrance susceptibility tumor marker [78].

When stratified according to ethnicity, our meta-analysis showed that the GG genotype was significantly associated with tumor risk in the Asian and European populations. According to some previously reported studies, the GG genotype is significantly associated with tumor risk in the Asian population, but not in the European population $[19,80,82]$. One possible reason is that our meta-analysis includes thirty-four European study
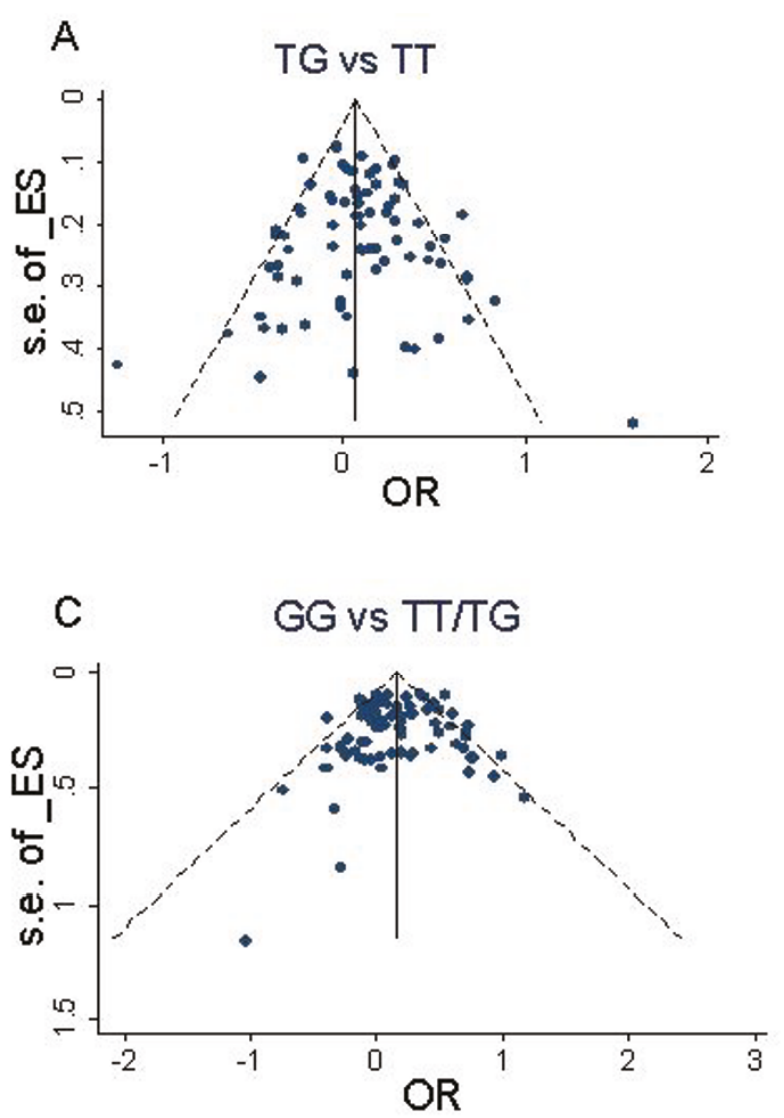
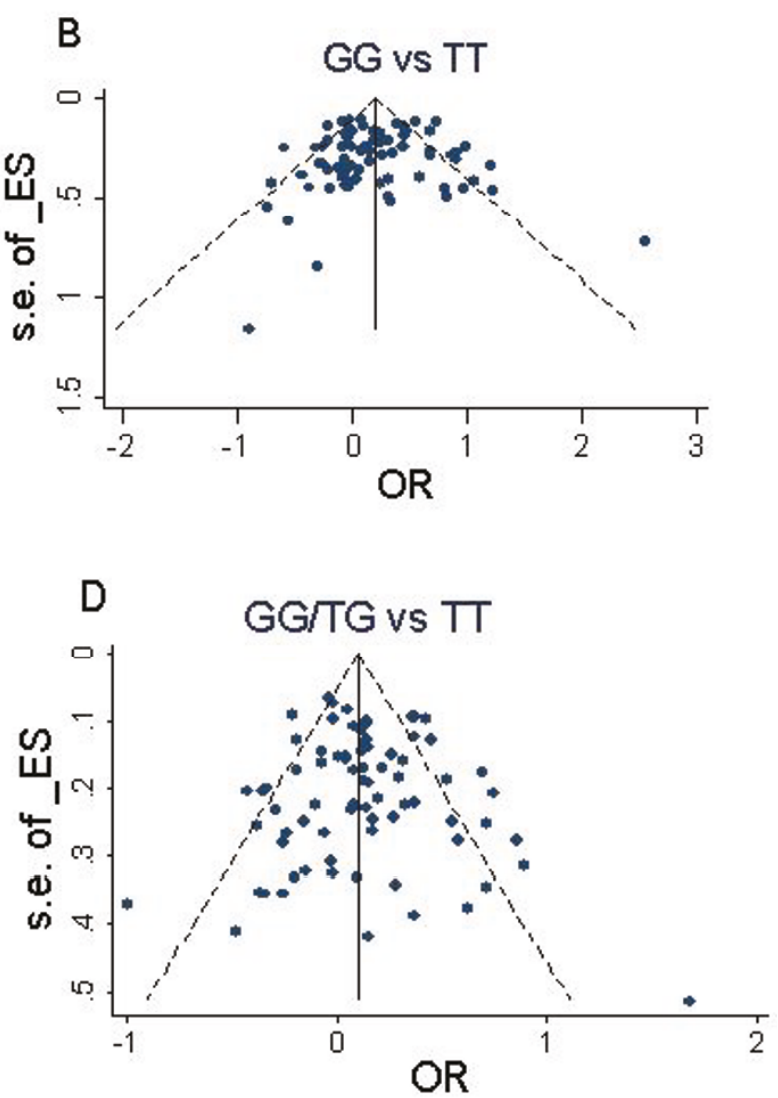

Figure 2 Funnel plot of association between MDM2 SNP309 and cancer risk 
comparisons, a large number of studies in comparison to previously reported comparisons. Consistent with previously reported studies, no significant associations were found in the African ethnic group [78]. This may suggest a potential role for ethnic differences in genetic backgrounds as well as environmental exposures. The mean MAF in the African group was 0.10, whereas in the Asian and European groups it was 0.50 and 0.38 , respectively. The large differences in the MAF between the African group and the Asian or European group may be a result of natural selection pressures, or balance due to other related genetic variants. Therefore, further studies regarding the MDM2 309T/G polymorphism in Africans and the underlying mechanism for ethnic differences are warranted.

In our meta-analysis, we included approximately thirty tumor types stratified into fourteen subgroups according to tumor location. In the subgroup analyses, we found a significant association in breast cancer but a non-significant association in lung cancer and colorectal cancer. Interestingly, our meta-analysis determined a significant association in brain, liver, stomach, and uterus cancer. The ORs for the GG genotype compared to TT was $1.18,2.24,1.54$, and 1.34, respectively. Similar findings have been reported in previous studies, including hepatocellular carcinoma associated with chronic hepatitis $\mathrm{C}$, gastric carcinoma, and sporadic endometrial carcinoma $[49,70,75]$, suggesting an interaction of MDM2 SNP309, infectious factor, and hormone factor.

In order to incorporate the p53 mutation status while investigating the effect of MDM2 SNP309 on tumors, we included seven studies to pool the patient genotypes according to the $p 53$ mutations $[16,20,21,35,37,41,54,70]$. However, we found no discrepancy between the two $p 53$ mutation groups, possibly due to insufficient statistical power. Furthermore, the functional polymorphism of the p53 codon 72 (Arg72Pro) had been shown to interact with SNP309 in the carcinogenesis of several carcinomas $[46,51,60,72]$. Our meta-analysis included six studies that explored interaction effects between $p 53$ Arg72Pro and MDM2 SNP309. We found that the OR for subjects with the MDM2 309 GG genotype and $p 5372$ Pro/Pro genotypes compared to subjects with MDM2 309 TT and $p 53$ 72Arg/Arg genotypes (3.38) was larger than the OR for subjects with the MDM2 309GG genotype and $p 53$ $72 \mathrm{Arg} / \mathrm{Arg}$ (1.96) or the OR for those with $M D M 2$ 309TT and $p 5372$ Pro/Pro (1.38). These results suggested a possible interaction effect between the MDM2 309GG and the p53 72 Pro/Pro genotype in increasing the risk of carcinogenesis.

The strength of our meta-analysis is due to the large number of comparisons included. However, our study does have a limitation: the controls in the studies included were not uniformly defined and thus the results presented here are based upon unadjusted estimates. A more precise analysis could be conducted with estimates adjusted according to covariates such as age, smoking, lifestyle, and environmental factors.

\section{Conclusions}

In summary, our results provide some support for the hypothesis that MDM2 SNP309 is associated with tumor risk and support the potential interaction effect between the MDM2 SNP309 and the polymorphism of p53 codon72. This investigation could be extended in future studies by incorporating other potential risk factors and p53-MDM2-related genes for tumor development.

\section{Additional material}

Additional file 1: Characteristics of included studies investigating

the association between MDM2 SNP309 and tumor risk.

\section{Acknowledgements}

This study was supported by grants no.LS2010168 from Liaoning Provincial Department of Education, and grant no.00726 from China Medical Board. The authors are most grateful to all the participants in this study.

\section{Author details}

'Department of Epidemiology, School of Public Health, China Medical University, Shenyang 110001, China. ${ }^{2}$ Key Laboratory of Cancer Etiology and Intervention, University of Liaoning Province, China. ${ }^{3}$ China Medical University Center For Evidence-based Medicine, Shenyang 110001, China.

\section{Authors' contributions}

YW carries out the meta-analysis study and drafted the manuscript. WW participates in the design of the study and performs the statistical analysis. ZY and WW collect and extract the data. PG has been involved in revising the manuscript critically for important intellectual content. BZ conceives of the study, and participates in its design and coordination and helps to draft the manuscript. All authors read and approve the final manuscript.

\section{Competing interests}

We declare that we have no financial and personal relationships with other people or organizations that can inappropriately influence our work; there is no professional or other personal interest of any nature or kind in any product, service and/or company that could be construed as influencing the position presented in, or the review of the manuscript. The authors

indicated no potential conflicts of interest.

Received: 28 September 2010 Accepted: 29 May 2011

Published: 29 May 2011

\section{References}

1. Vogelstein B, Lane D, Levine AJ: Surfing the p53 network. Nature 2000, 408(6810):307-310.

2. Levine AJ: p53, the cellular gatekeeper for growth and division. Cell 1997, 88(3):323-331.

3. Bourdon JC, Laurenzi VD, Melino G, Lane D: p53: 25 years of research and more questions to answer. Cell Death Differ 2003, 10(4):397-399.

4. Feki A, Irminger-Finger I: Mutational spectrum of p53 mutations in primary breast and ovarian tumors. Crit Rev Oncol Hematol 2004, 52(2):103-116.

5. Kussie PH, Gorina S, Marechal V, Elenbaas B, Moreau J, Levine AJ, Pavletich NP: Structure of the MDM2 oncoprotein bound to the p53 tumor suppressor transactivation domain. Science 1996, 274(5289):948-953. 
6. Oren M, Damalas A, Gottlieb T, Michael D, Taplick J, Leal JF, Maya R, Moas M, Seger R, Taya Y, Ben-Ze'ev A: Regulation of p53: intricate loops and delicate balances. Biochem Pharmacol 2002, 64(5-6):865-871.

7. Bouska A, Lushnikova T, Plaza S, Eischen CM: Mdm2 promotes genetic instability and transformation independent of p53. Mol Cell Biol 2008, 28(15):4862-4874.

8. Bond GL, Hu W, Bond EE, Robins H, Lutzker SG, Arva NC, Bargonetti Bartel F, Taubert H, Wuerl P, Onel K, Yip L, Hwang SJ, Strong LC, Lozano G, Levine AJ: A single nucleotide polymorphism in the MDM2 promoter attenuates the $\mathrm{p} 53$ tumor suppressor pathway and accelerates tumor formation in humans. Cell 2004, 119(5):591-602.

9. Bond $\mathrm{GL}, \mathrm{Hu} \mathrm{W}$, Levine AJ: MDM2 is a central node in the $\mathrm{p} 53$ pathway: 12 years and counting. Curr Cancer Drug Targets 2005, 5(1):3-8.

10. Marcel V, Palmero El, Falagan-Lotsch P, Martel-Planche G, Ashton-Prolla P, Olivier M, Brentani RR, Hainaut P, Achatz MI: TP53 PIN3 and MDM2 SNP309 polymorphisms as genetic modifiers in the Li-Fraumeni syndrome: impact on age at first diagnosis. J Med Genet 2009, 46(11):766-772.

11. Oliner JD, Kinzler KW, Meltzer PS, George DL, Vogelstein B: Amplification of a gene encoding a p53-associated protein in human sarcomas. Nature 1992, 358(6381):80-83.

12. Cattelani S, Defferrari R, Marsilio S, Bussolari R, Candini O, Corradini F, Ferrari-Amorotti G, Guerzoni C, Pecorari L, Menin C, Bertorelle R, Altavista P, McDowell HP, Boldrini R, Dominici C, Tonini GP, Raschella G, Calabretta B: Impact of a single nucleotide polymorphism in the MDM2 gene on neuroblastoma development and aggressiveness: results of a pilot study on 239 patients. Clin Cancer Res 2008, 14(11):3248-3253.

13. El Hallani S, Marie Y, Idbaih A, Rodero M, Boisselier B, Laigle-Donadey F, Ducray F, Delattre JY, Sanson M: No association of MDM2 SNP309 with risk of glioblastoma and prognosis. J Neurooncol 2007, 85(3):241-244

14. Khatri RG, Navaratne $K$, Weil RJ: The role of a single nucleotide polymorphism of MDM2 in glioblastoma multiforme. J Neurosurg 2008, 109(5):842-848.

15. Perfumo C, Parodi S, Mazzocco K, Defferrari R, Inga A, Scarra GB, Ghiorzo P, Haupt R, Tonini GP, Fronza G: MDM2 SNP309 genotype influences survival of metastatic but not of localized neuroblastoma. Pediatr Blood Cancer 2009, 53(4):576-583.

16. Tsuiki H, Nishi T, Takeshima H, Yano S, Nakamura H, Makino K, Kuratsu J: Single nucleotide polymorphism 309 affects murin-double-minute 2 protein expression but not glioma tumorigenesis. Neurol Med Chir (Tokyo) 2007, 47(5):203-208, discussion 208-209.

17. Boersma BJ, Howe TM, Goodman JE, Yfantis HG, Lee DH, Chanock SJ, Ambs S: Association of breast cancer outcome with status of $\mathrm{p} 53$ and MDM2 SNP309. I Natl Cancer Inst 2006, 98(13):911-919.

18. Campbell IG, Eccles DM, Choong DY: No association of the MDM2 SNP309 polymorphism with risk of breast or ovarian cancer. Cancer Lett 2006, 240(2):195-197.

19. Cox DG, Deer D, Guo Q, Tworoger SS, Hankinson SE, Hunter DJ, De Vivo I: The p53 Arg72Pro and MDM2 -309 polymorphisms and risk of breast cancer in the nurses' health studies. Cancer Causes Control 2007, 18(6):621-625.

20. Krekac D, Brozkova K, Knoflickova D, Hrstka R, Muller P, Nenutil R, Vojtesek B: MDM2SNP309 does not associate with elevated MDM2 protein expression or breast cancer risk. Oncology 2008, 74(1-2):84-87.

21. Lang A, Palmeback Wegman P, Wingren S: The significance of MDM2 SNP309 and p53 Arg72Pro in young women with breast cancer. Oncol Rep 2009, 22(3):575-579.

22. Lum SS, Chua HW, Li H, Li WF, Rao N, Wei J, Shao Z, Sabapathy K: MDM2 SNP309 $\mathrm{G}$ allele increases risk but the T allele is associated with earlier onset age of sporadic breast cancers in the Chinese population. Carcinogenesis 2008, 29(4):754-761.

23. Ma H, Hu Z, Zhai X, Wang S, Wang X, Qin J, Jin G, Liu J, Wang X, Wei $Q$ Shen H: Polymorphisms in the MDM2 promoter and risk of breast cancer: a case-control analysis in a Chinese population. Cancer Lett 2006, 240(2):261-267.

24. Millikan RC, Heard K, Winkel S, Hill EJ, Heard K, Massa B, Mayes L, Williams P, Holston R, Conway K, Edmiston S, de Cotret AR: No association between the MDM2 -309 T/G promoter polymorphism and breast cancer in African-Americans or Whites. Cancer Epidemiol Biomarkers Prev 2006 15(1):175-177.
25. Onat OE, Tez M, Ozcelik T, Toruner GA: MDM2 T309G polymorphism is associated with bladder cancer. Anticancer Res 2006, 26(5A):3473-3475.

26. Paulin FE, O'Neill M, McGregor G, Cassidy A, Ashfield A, Ali CW, Munro AJ, Baker L, Purdie CA, Lane DP, Thompson AM: MDM2 SNP309 is associated with high grade node positive breast tumours and is in linkage disequilibrium with a novel MDM2 intron 1 polymorphism. BMC Cancer 2008, 8:281.

27. Petenkaya A, Bozkurt B, Akilli-Ozturk O, Kaya HS, Gur-Dedeoglu B, Yulug IG Lack of association between the MDM2-SNP309 polymorphism and breast cancer risk. Anticancer Res 2006, 26(6C):4975-4977.

28. Singh V, Rastogi N, Mathur N, Singh K, Singh MP: Association of polymorphism in MDM-2 and p53 genes with breast cancer risk in Indian women. Ann Epidemiol 2008, 18(1):48-57.

29. Sun YF, Leu JD, Chen SM, Lin IF, Lee YJ: Results based on 124 cases of breast cancer and 97 controls from Taiwan suggest that the single nucleotide polymorphism (SNP309) in the MDM2 gene promoter is associated with earlier onset and increased risk of breast cancer. BMC Cancer 2009, 9:13.

30. Wasielewski M, Nagel JH, Brekelmans C, Klijn JG, van den Ouweland A, Meijers-Heijboer H, Schutte M: MDM2 SNP309 accelerates familial breast carcinogenesis independently of estrogen signaling. Breast Cancer Res Treat 2007, 104(2):153-157.

31. Wilkening S, Bermejo JL, Burwinkel B, Klaes R, Bartram CR, Meindl A, Bugert P, Schmutzler RK, Wappenschmidt B, Untch M, Hemminki K, Forsti A: The single nucleotide polymorphism IVS1+309 in mouse double minute 2 does not affect risk of familial breast cancer. Cancer Res 2006, 66(2):646-648

32. Wilkening S, Hemminki K, Rudnai P, Gurzau E, Koppova K, Forsti A, Kumar R: No association between MDM2 SNP309 promoter polymorphism and basal cell carcinoma of the skin. Br J Dermatol 2007, 157(2):375-377.

33. Yarden Rl, Friedman E, Metsuyanim S, Olender T, Ben-Asher E, Papa MZ: MDM2 SNP309 accelerates breast and ovarian carcinogenesis in BRCA1 and BRCA2 carriers of Jewish-Ashkenazi descent. Breast Cancer Res Treat 2008, 111(3):497-504.

34. Alhopuro P, Ylisaukko-Oja SK, Koskinen WJ, Bono P, Arola J, Jarvinen HJ, Mecklin JP, Atula T, Kontio R, Makitie AA, Suominen S, Leivo I, Vahteristo P, Aaltonen LM, Aaltonen LA: The MDM2 promoter polymorphism SNP309T-> G and the risk of uterine leiomyosarcoma, colorectal cancer, and squamous cell carcinoma of the head and neck. J Med Genet 2005, 42(9):694-698.

35. Alazzouzi H, Suriano G, Guerra A, Plaja A, Espin E, Armengol M, Alhopuro P, Velho S, Shinomura Y, Gonzalez-Aguilera JJ, Yamamoto H, Aaltonen LA, Moreno V, Capella G, Peinado MA, Seruca R, Arango D, Schwartz S Jr: Tumour selection advantage of non-dominant negative P53 mutations in homozygotic MDM2-SNP309 colorectal cancer cells. J Med Genet 2007, 44(1):75-80

36. Liu JN, Zhang XM, Guo YL, Sun T, Lin DX, Wen T: Genetic polymorphism in MDM2 is associated with susceptibility to colorectal cancer in a Chinese population. Zhonghua Zhong Liu Za Zhi 2008, 30(5):335-338

37. Menin C, Scaini MC, De Salvo GL, Biscuola M, Quaggio M, Esposito G, Belluco C, Montagna M, Agata S, D'Andrea E, Nitti D, Amadori A, Bertorelle R: Association between MDM2 SNP309 and age at colorectal cancer diagnosis according to p53 mutation status. J Natl Cancer Inst 2006, 98(4):285-288.

38. Sotamaa K, Liyanarachchi S, Mecklin JP, Jarvinen H, Aaltonen LA, Peltomaki P, de la Chapelle A: p53 codon 72 and MDM2 SNP309 polymorphisms and age of colorectal cancer onset in Lynch syndrome. Clin Cancer Res 2005, 11(19 Pt 1):6840-6844.

39. Cao YY, Zhang XF, Guo W, Wang R, Ge H, Zhang JH: Association of the MDM2 polymorphisms with susceptibility of esophageal squamous cell carcinoma and that of gastric cardiac adenocarcinoma. Tumor 2007, , 8: 628-632.

40. Hong Y, Miao X, Zhang X, Ding F, Luo A, Guo Y, Tan W, Liu Z, Lin D: The role of P53 and MDM2 polymorphisms in the risk of esophageal squamous cell carcinoma. Cancer Res 2005, 65(20):9582-9587.

41. Huang SF, Chen IH, Liao CT, Wang HM, Liou SH, Hsieh LL: Combined effects of MDM2 SNP 309 and p53 mutation on oral squamous cell carcinomas associated with areca quid chewing. Oral Oncol 2009, 45(1):16-22 
42. Misra C, Majumder M, Bajaj S, Ghosh S, Roy B, Roychoudhury S: Polymorphisms at p53, p73, and MDM2 loci modulate the risk of tobacco associated leukoplakia and oral cancer. Mol Carcinog 2009, 48(9):790-800.

43. Zhou G, Zhai $Y$, Cui $Y$, Zhang $X$, Dong $X$, Yang $H$, He $Y$, Yao $K$, Zhang $H$, Zhi L, Yuan X, Qiu W, Zhang X, Shen Y, Qiang B, He F: MDM2 promoter SNP309 is associated with risk of occurrence and advanced lymph node metastasis of nasopharyngeal carcinoma in Chinese population. Clin Cancer Res 2007, 13(9):2627-2633.

44. Do TN, Ucisik-Akkaya E, Davis CF, Morrison BA, Dorak MT: TP53 R72P and MDM2 SNP309 polymorphisms in modification of childhood acute lymphoblastic leukemia susceptibility. Cancer Genet Cytogenet 2009, 195(1):31-36.

45. Phang BH, Linn YC, Li H, Sabapathy K: MDM2 SNP309 G allele decreases risk but does not affect onset age or survival of Chinese leukaemia patients. Eur J Cancer 2008, 44(5):760-766.

46. Xiong X, Wang M, Wang L, Liu J, Zhao X, Tian Z, Wang J: Risk of MDM2 SNP309 alone or in combination with the p53 codon 72 polymorphism in acute myeloid leukemia. Leuk Res 2009, 33(11):1454-1458.

47. Zenz T, Habe S, Benner A, Kienle D, Dohner H, Stilgenbauer S: The MDM2 -309 T/G promoter single nucleotide polymorphism does not alter disease characteristics in chronic lymphocytic leukemia. Haematologica 2008, 93(7):1111-1113.

48. Dharel N, Kato N, Muroyama R, Moriyama M, Shao RX, Kawabe T, Omata M: MDM2 promoter SNP309 is associated with the risk of hepatocellular carcinoma in patients with chronic hepatitis C. Clin Cancer Res 2006, 12(16):4867-4871.

49. Ezzikouri S, El Feydi AE, Afifi R, El Kihal L, Benazzouz M, Hassar M, Marchio A, Pineau P, Benjelloun S: MDM2 SNP309T > G polymorphism and risk of hepatocellular carcinoma: a case-control analysis in a Moroccan population. Cancer Detect Prev 2009, 32(5-6):380-385

50. Leu JD, Lin IF, Sun YF, Chen SM, Liu CC, Lee YJ: Association between MDM2-SNP309 and hepatocellular carcinoma in Taiwanese population. World J Gastroenterol 2009, 15(44):5592-5597.

51. Yoon YJ, Chang HY, Ahn SH, Kim JK, Park YK, Kang DR, Park JY, Myoung SM, Kim do Y, Chon CY, Han KH: MDM2 and p53 polymorphisms are associated with the development of hepatocellular carcinoma in patients with chronic hepatitis B virus infection. Carcinogenesis 2008, 29(6):1192-1196.

52. Hu Z, Ma H, Lu D, Qian J, Zhou J, Chen Y, Xu L, Wang X, Wei Q, Shen H: Genetic variants in the MDM2 promoter and lung cancer risk in a Chinese population. Int J Cancer 2006, 118(5):1275-1278.

53. Li G, Zhai X, Zhang Z, Chamberlain RM, Spitz MR, Wei Q: MDM2 gene promoter polymorphisms and risk of lung cancer: a case-control analysis. Carcinogenesis 2006, 27(10):2028-2033.

54. Lind $\mathrm{H}$, Zienolddiny $\mathrm{S}$, Ekstrom $\mathrm{PO}$, Skaug $\mathrm{V}$, Haugen $\mathrm{A}$ : Association of a functional polymorphism in the promoter of the MDM2 gene with risk of nonsmall cell lung cancer. Int J Cancer 2006, 119(3):718-721.

55. Liu G, Wheatley-Price P, Zhou W, Park S, Heist RS, Asomaning K, Wain JC, Lynch TJ, Su L, Christiani DC: Genetic polymorphisms of MDM2, cumulative cigarette smoking and nonsmall cell lung cancer risk. Int J Cancer 2008, 122(4):915-918.

56. Mittelstrass K, Sauter W, Rosenberger A, Illig T, Timofeeva M, Klopp N, Dienemann H, Meese E, Sybrecht G, Woelke G, Cebulla M, Degen M, Morr H, Drings P, Groeschel A, Kreymborg KG, Haeussinger K, Hoeffken G, Schmidt C, Jilge B, Schmidt W, Ko YD, Taeuscher D, Chang-Claude J, Wichmann HE, Bickeboeller H, Risch A: Early onset lung cancer, cigarette smoking and the SNP309 of the murine double minute-2 (MDM2) gene. BMC Cancer 2008, 8:113.

57. Mu XF: The Analysis of the Polymorphism of PUS2 and MDM2 Genes in Non-Small Cell Lung Cancer among Chinese Population. Master Degree Beijing, China: Peking Union Medical College; 2006

58. Park SH, Choi JE, Kim EJ, Jang JS, Han HS, Lee WK, Kang YM, Park JY: MDM2 309T > G polymorphism and risk of lung cancer in a Korean population. Lung Cancer 2006, 54(1):19-24.

59. Pine SR, Mechanic LE, Bowman ED, Welsh JA, Chanock SC, Shields PG Harris CC: MDM2 SNP309 and SNP354 are not associated with lung cancer risk. Cancer Epidemiol Biomarkers Prev 2006, 15(8):1559-1561.

60. Zhang X, Miao X, Guo Y, Tan W, Zhou Y, Sun T, Wang Y, Lin D: Genetic polymorphisms in cell cycle regulatory genes MDM2 and TP53 are associated with susceptibility to lung cancer. Hum Mutat 2006, 27(1):110-117.
61. Hirata H, Hinoda Y, Kikuno N, Kawamoto K, Suehiro Y, Tanaka Y, Dahiya R: MDM2 SNP309 polymorphism as risk factor for susceptibility and poor prognosis in renal cell carcinoma. Clin Cancer Res 2007, 13(14):4123-4129.

62. Horikawa Y, Nadaoka J, Saito M, Kumazawa T, Inoue T, Yuasa T, Tsuchiya N, Nishiyama H, Ogawa O, Habuchi T: Clinical implications of the MDM2 SNP309 and p53 Arg72Pro polymorphisms in transitional cell carcinoma of the bladder. Oncol Rep 2008, 20(1):49-55.

63. Stoehr R, Hitzenbichler F, Kneitz B, Hammerschmied CG, Burger M, Tannapfel A, Hartmann A: Mdm2-SNP309 polymorphism in prostate cancer: no evidence for association with increased risk or histopathological tumour characteristics. Br J Cancer 2008, 99(1):78-82.

64. Kang S, Wang DJ, Li WS, Wang N, Zhou RM, Sun DL, Duan YN, Li SZ, Li XF, Li Y: Association of p73 and MDM2 polymorphisms with the risk of epithelial ovarian cancer in Chinese women. Int J Gynecol Cancer 2009, 19(4):572-577.

65. Ueda M, Yamamoto M, Nunobiki O, Toji E, Sato N, Izuma S, Okamoto Y, Torii K, Noda S: Murine double-minute 2 homolog single nucleotide polymorphism 309 and the risk of gynecologic cancer. Hum Cell 2009, 22(2):49-54.

66. Asomaning K, Reid AE, Zhou W, Heist RS, Zhai R, Su L, Kwak EL, Blaszkowsky L, Zhu AX, Ryan DP, Christiani DC, Liu G: MDM2 promoter polymorphism and pancreatic cancer risk and prognosis. Clin Cancer Res 2008, 14(12):4010-4015.

67. Grochola LF, Muller TH, Bond GL, Taubert H, Udelnow A, Wurl P: MDM2 SNP309 associates with accelerated pancreatic adenocarcinoma formation. Pancreas 39(1):76-80.

68. Nan H, Qureshi AA, Hunter DJ, Han J: A functional SNP in the MDM2 promoter, pigmentary phenotypes, and risk of skin cancer. Cancer Causes Control 2009, 20(2):171-179.

69. Cho YG, Choi BJ, Song JH, Kim CJ, Cao Z, Nam SW, Lee JY, Park WS: No association of MDM2 T309G polymorphism with susceptibility to Korean gastric cancer patients. Neoplasma 2008, 55(3):256-260.

70. Ohmiya N, Taguchi A, Mabuchi N, Itoh A, Hirooka Y, Niwa Y, Goto H: MDM2 promoter polymorphism is associated with both an increased susceptibility to gastric carcinoma and poor prognosis. J Clin Oncol 2006, 24(27):4434-4440.

71. Wang $X$, Yang J, Ho B, Yang $Y$, Huang Z, Zhang Z, Zhang G: Interaction of Helicobacter pylori with genetic variants in the MDM2 promoter, is associated with gastric cancer susceptibility in Chinese patients. Helicobacter 2009, 14(5):114-119.

72. Yang M, Guo Y, Zhang X, Miao X, Tan W, Sun T, Zhao D, Yu D, Liu J, Lin D: Interaction of P53 Arg72Pro and MDM2 T309G polymorphisms and their associations with risk of gastric cardia cancer. Carcinogenesis 2007 28(9):1996-2001.

73. Ashton KA, Proietto A, Otton G, Symonds I, McEvoy M, Attia J, Gilbert M, Hamann U, Scott RJ: Polymorphisms in TP53 and MDM2 combined are associated with high grade endometrial cancer. Gynecol Oncol 2009, 113(1):109-114.

74. Meissner Rde V, Barbosa RN, Fernandes JV, Galvao TM, Galvao AF, Oliveira GH: No association between SNP309 promoter polymorphism in the MDM2 and cervical cancer in a study from northeastern Brazil. Cancer Detect Prev 2007, 31(5):371-374.

75. Nunobiki O, Ueda M, Yamamoto M, Toji E, Sato N, Izuma S, Okamoto Y Torii K, Noda S: Polymorphisms of p53 codon 72 and MDM2 promoter 309 and the risk of endometrial cancer. Hum Cell 2009, 22(4):101-106.

76. Terry K, McGrath M, Lee IM, Buring J, De Vivo I: MDM2 SNP309 is associated with endometrial cancer risk. Cancer Epidemiol Biomarkers Prev 2008, 17(4):983-986.

77. Walsh CS, Miller CW, Karlan BY, Koeffler HP: Association between a functional single nucleotide polymorphism in the MDM2 gene and sporadic endometrial cancer risk. Gynecol Oncol 2007, 104(3):660-664.

78. Hu Z, Jin $G$, Wang $L$, Chen $F$, Wang $X$, Shen H: MDM2 promoter polymorphism SNP309 contributes to tumor susceptibility: evidence from 21 case-control studies. Cancer Epidemiol Biomarkers Prev 2007, 16(12):2717-2723.

79. Wilkening S, Bermejo JL, Hemminki K: MDM2 SNP309 and cancer risk: a combined analysis. Carcinogenesis 2007, 28(11):2262-2267.

80. Gui XH, Qiu LX, Zhang HF, Zhang DP, Zhong WZ, Li J, Xiao YL: MDM2 309 T/G polymorphism is associated with lung cancer risk among Asians. Eur J Cancer 2009, 45(11):2023-2026. 
81. Bai J, Dai J, Yu H, Shen H, Chen F: Cigarette smoking, MDM2 SNP309, gene-environment interactions, and lung cancer risk: a meta-analysis. $J$ Toxicol Environ Health A 2009, 72(11-12):677-682.

82. Economopoulos KP, Sergentanis TN: Differential effects of MDM2 SNP309 polymorphism on breast cancer risk along with race: a meta-analysis. Breast Cancer Res Treat 2010, 120(1):211-216.

\section{Pre-publication history}

The pre-publication history for this paper can be accessed here: http://www.biomedcentral.com/1471-2407/11/208/prepub

doi:10.1186/1471-2407-11-208

Cite this article as: Wan et al:: MDM2 SNP309, gene-gene interaction, and tumor susceptibility: an updated meta-analysis. BMC Cancer 2011

$11: 208$

Submit your next manuscript to BioMed Central and take full advantage of:

- Convenient online submission

- Thorough peer review

- No space constraints or color figure charges

- Immediate publication on acceptance

- Inclusion in PubMed, CAS, Scopus and Google Scholar

- Research which is freely available for redistribution

Submit your manuscript at www.biomedcentral.com/submit 